\title{
VARIATIONS IN SURFACE VELOCITIES OF TIDEWATER GLACIERS OF THE ANTARCTIC PENINSULA BETWEEN THE PERIODS 1988-1991 AND 2000-2003
}

\author{
Aline B. Silva, Jorge Arigony-Neto, Cláudio W. Mendes-Júnior and Adriano G. Lemos
}

\begin{abstract}
In the Antarctic Peninsula, recent events of glacier retreat, disintegration and break-up of ice shelves indicated that ice masses in this region are reacting rapidly to the increasing trend in oceanic and surface air temperatures. This study aimed to define variations in ice flow velocity of tidewater glaciers between the periods of 1988-1991 and 2000-2003, in northeastern, northwestern and midwestern Marguerite Bay and Larsen C ice shelf sectors. Glacier velocities were estimated by the application of a cross-correlation algorithm of IMCORR software in multitemporal LANDSAT TM/ETM+ images. Moreover, we used monthly mean oceanic and air temperature data from OCCAM and ERA-Interim models, respectively. Ice flow velocities on the northeastern sector was $0.24 \pm 0.12 \mathrm{md}^{-1}$ in the period 1988 1991, while in 2000-2002 it was $0.06 \pm 0.02 \mathrm{md}^{-1}$. In the northwestern part of the peninsula, the mean glacier velocity was $0.10 \pm 0.005 \mathrm{md}^{-1}$ between 1989 and 1990, and $0.22 \pm 0.13 \mathrm{md}^{-1}$ between 2000 and 2001. In the Midwestern sector, the mean velocity of glaciers was $1.06 \pm 0.86 \mathrm{md}^{-1}$ in the period 1989-1991, and $0.84 \pm 0.78 \mathrm{md}^{-1}$ in the period 2000-2001. In Marguerite Bay, the velocity was $1.28 \pm 0.77 \mathrm{md}^{-1}$ in the period 1988-1989, characterized by temperatures near $0^{\circ} \mathrm{C}$ in the Bellingshausen Sea, while in the period 2000-2001, with mean ocean temperatures close to $-2^{\circ} \mathrm{C}$, the mean glacier velocity was significantly lower, of $0.23 \pm 0.12 \mathrm{md}^{-1}$. Finally, in Larsen C ice shelf, the mean velocity ranged from $0.80 \pm 0.20 \mathrm{md}^{-1}$, between 1988 and 1989 , to $0.15 \pm 0.10 \mathrm{md}^{-1}$, between 2000 and 2003. The higher speed of flow of tidewater glaciers between 1988 and 1991 occurred in a period when the mean surface air and sea temperatures also were higher.
\end{abstract}

Keywords: Antarctic Peninsula, remote sensing, glacier dynamics.

RESUMO. Na Península Antártica, recentes eventos de retração de frentes de geleiras, desintegração e fragmentação de plataformas de gelo indicam que as massas de gelo dessa região estão reagindo rapidamente à tendência de aumento nas temperaturas oceânicas e do ar superficial. 0 objetivo deste estudo foi determinar variações na velocidade superficial de fluxo de geleiras de maré dessa península entre os períodos 1988-1991 e 2000-2003, nos setores nordeste, noroeste, centro-oeste, baía Marguerite e plataforma de gelo Larsen C. Essas variações foram estimadas pela aplicação do algoritmo de correlação cruzada do programa IMCORR em imagens multitemporais LANDSAT TM/ETM+. Além disso, foram utilizados dados de temperatura média mensal oceânica e do ar superficial dos modelos OCCAM e ERA-Interim, respectivamente. No setor nordeste a velocidade média das geleiras foi de 0,24 $\pm 0,12 \mathrm{md}^{-1}$ no período 1988-1991, e em 2000-2002 foi de 0,06 $\pm 0,02 \mathrm{md}^{-1}$. No setor noroeste a velocidade de fluxo encontrada foi de 0,10 $\pm 0,005 \mathrm{md}^{-1}$, entre 1989 e 1990, e de 0,22 $\pm 0,13 \mathrm{md}^{-1}$, entre 2000 e 2001. No setor centro-oeste, a velocidade foi de 1,06 0,86 md $\mathrm{m}^{-1}$ entre 1989 e 1991, e de 0,84 $\pm 0,78 \mathrm{md}^{-1}$ entre 2000 e 2001. Na Baía Marguerite, a velocidade superficial das geleiras foi de 1,28 $\pm 0,77 \mathrm{md}^{-1}$ no período 1988-1989, com temperaturas médias próximas a $0^{\circ} \mathrm{C}$ no mar de Bellingshausen, enquanto que no período 2000-2001, com temperaturas médias próximas a $-2^{\circ} \mathrm{C}$ foi estimada uma velocidade média de $0,23 \pm 0,12 \mathrm{md}^{-1}$. Nas geleiras tributárias da plataforma de gelo Larsen C, a velocidade oscilou de 0,80 $\pm 0,20 \mathrm{md}^{-1}$, em 1988-1989, para 0,15 $\pm 0,10 \mathrm{md}^{-1}$, em 2000-2003. A maior velocidade de fluxo das geleiras de maré entre 1988 a 1991 ocorreu em um período em que as médias de temperatura do ar superficial e oceânica também estavam mais elevadas.

Palavras-chave: Península Antártica, sensoriamento remoto, dinâmica glacial.

Laboratório de Monitoramento da Criosfera - LaCrio, Programa de Pós-Graduação em Oceanografia Física, Química e Geológica, Universidade Federal do Rio Grande - FURG, Av. Itália, Km 8, 96203-900 Rio Grande, RS, Brazil. Phone: +55(53) 3233-6845

-E-mails: linebsilva@yahoo.com.br; jorgearigony@furg.br; geoclaudio@yahoo.com.br; adrianolemosefei@gmail.com 


\section{INTRODUCTION}

The main objective of this study was to estimate and analyze variations in the speed of flow of tidewater glaciers on the Antarctic Peninsula during the periods 1988-1991 and 2000-2003, using data from LANDSAT sensors TM and ETM+, and identify the occurrence of temporal and spatial variations at this speed. In addition, to evaluate the influence of ocean and surface air temperatures in these variations.

Antarctica has an important function in the climate of planet Earth, because variations in the extent of the Antarctic ice sheet and ice shelves affect the radiation balance of earth and ocean circulation (King \& Turner, 1997). Moreover, climate models show that the effects of climate change are amplified in the polar regions (Rees, 2006). In the Antarctic Peninsula, the recent sequence of events of disintegration and fragmentation of ice shelves, in addition to the retreat of tidewater glaciers, indicated that the ice masses in this region are reacting quickly to the increasing trend in surface air temperature observed during the last decades in this region (Pritchard \& Vaughan, 2007).

An important parameter to understanding the dynamics of these masses of snow and ice is the speed of surface flow, which, together with ice thickness, allows the determination of rates of discharge of the same. This parameter can be measured using remote sensing data used to identify similar features on the surface of glaciers (e.g., crevasses) in multitemporal images. The measured difference between the position of these features in sequential pairs of images provides information about the displacement speed of glaciers (Scambos et al., 1992).

\section{Dynamics of glaciers}

A glacier is a mass of snow and ice continuously moving by creep and basal sliding (Simões, 2004). Glaciers are formed by accumulation of successive layers of compacted and recrystallized snow in regions where snow accumulation over a year is greater than the loss of snow and ice. It moves slowly raised down, due to gravity, causing erosion and sedimentation. Glaciers can be divided into zones or facies, according to the change of their surface and internal characteristics (Cuffey \& Paterson, 2010).

The dynamics of a glacier depends on several factors, including climate and topography (Nesje \& Dahl, 2000). The weather will control the speed at which glacier will form, from the moment that the annual accumulation exceeds the annual snowmelt. The balance between the accumulation, that corresponds to the direct precipitation of snow, ice or rain, condensation of ice from water vapor, transport of snow and ice to the glacier or avalanche
(Simões, 2004), and ablation of snow, such as melting, evaporation, sublimation, wind erosion, avalanches, will establish the mass balance of the glacier (Bennett \& Glasser, 2009). The topography will determine the degree of inclination of the bedrock under the glacier and the incidence of solar radiation on the surface (Nesje \& Dahl, 2000).

The processes of transformation of snow to ice are important factors in determining the flow of a glacier. These factors include the movement of the ice crystal, changes in shape, size and internal deformation of the crystal (Nesje \& Dahl, 2000). Ice is polycrystalline, where their crystals are oriented with their more or less regular edges consisting of parallel molecules in hexagonal rings in a visco-plastic material which deformation increases rapidly with increasing pressure. Its hardness is determined by the temperature, the lower the temperature, the higher the hardness (Nesje \& Dahl, 2000).

The precipitated snow does not change its structure after deposit and reaches the intermediate stage between snow and ice in the firn form (Hambrey, 1994). The firn is the stage where the ice crystals are already clusters (Simões, 2004). The change from this stage to the ice occurs when the connections between the firn pores are closed which usually occurs at a density of $830 \mathrm{~kg} \mathrm{~m}^{-3}$.

The water that comes to the glacier, whether on the surface or base, is at higher temperatures, since probably originated from the precipitation of rain or snow melting of the glacier. When this water percolating and refreezing at the glacier will dilate it (Hambrey, 1994). The dilation occurs because in its solid state water presents a crystal structure with large spaces between the particles. The melting ice will result in breaking these links, resulting in a reduction of $10 \%$ of its previous former volume. Already solidification of water causes an increase of its initial volume, causing the expansion of crevasses and canals through which the water flowed.

Figure 1 illustrates the glacier hydrology, showing the percolation of water into a glacier during ablation season. The melt water percolates through the crevasses of the glacier with velocities of a few meters per second, and part of this water arrives the zone of contact of the ice with the rock through tunnels of subglacial drainage supplied by crevasses or moulins (i.e., vertical cannals formed by water melting), causing the glacier basal lubrication (Zwally et al., 2002), and partly returns to the surface by upwelling (Cuffey \& Paterson, 2010).

To estimate the internal deformation of a glacier, you must use two parameters: the thickness of the ice, which determines the baseline tension, and surface inclination. Empirical evidence have shown that the vast majority of glaciers flowing over his rigid 


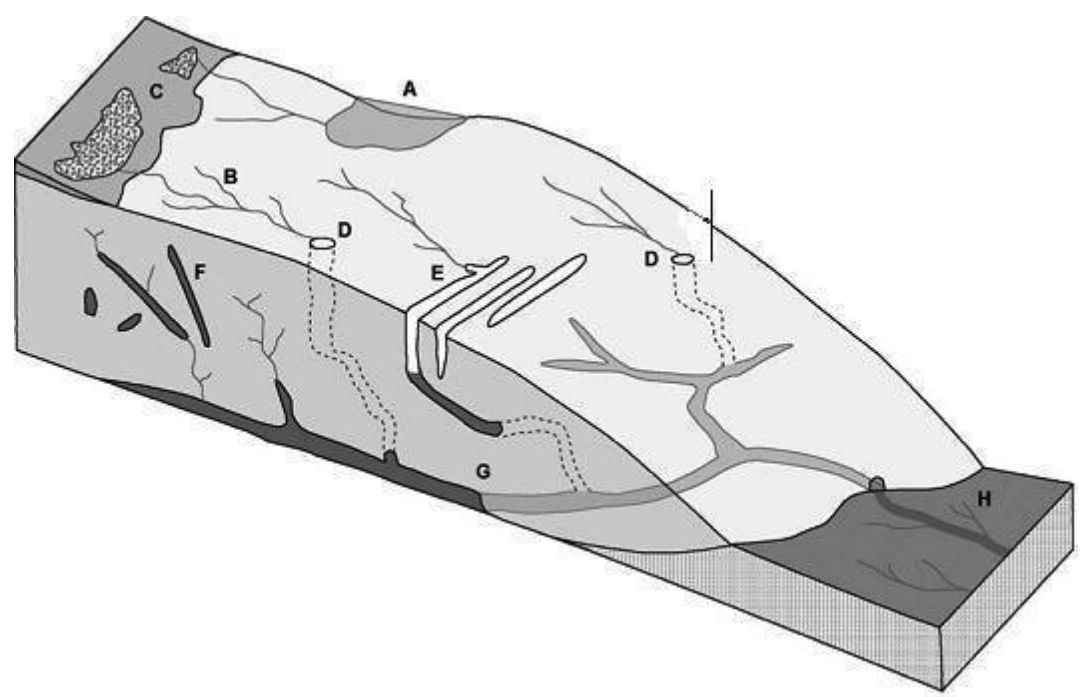

Figure 1 - Elements of the drainage system of a glacier. A - Supraglacial lakes. B - Flow channels at the surface. C - Areas near the limit of the firn. D - Moulins or subglacial drainage tunnels (for scale line is $10 \mathrm{~m}$ height). $\mathrm{E}$ - Crevasses in the ice. F-Fractures with water. G - Subglacial tunnels exit at the front of the glacier. $\mathrm{H}$ - Discharge of the glacier, from tunnels and also upwelling groundwater. Source: Modified from Cuffey \& Paterson (2010).

substrate presented a basal shear tension between 50 and $150 \mathrm{kPa}$ (Bennett \& Glasser, 2009). However, the internal deformation is not the only factor in the movement of a glacier, either the principal. In its substrate, friction occurs with sediment and thus the glacier does not move only by the internal properties of the ice, but also the force of friction with the sediment (Bennett \& Glasser, 2009). Furthermore, the topography is a determinant factor for the displacement of glaciers, since its inclination will make gravity to act more or less about the process of moving.

The acceleration and deceleration of ice also define the patterns of ice flow, combined with the internal deformation and basal slip (Hambrey, 1994), as showed in Figure 2. However, each glacier may respond differently to the same environmental conditions (Cook et al., 2005).

In order to form a crevasse, an elastic deformation on the ice is needed, for this to occur there must be a critical limit of surface tension, with values between 90 and $320 \mathrm{kPa}$ (Nath \& Vaughan, 2003). Since the tension formed by the internal deformation of ice is not always the same, different types of crevasses will form on the surface of glaciers. The layout of the crevasses indicates whether the glacier has accelerated its movement, keeps flowing or decelerated constant velocity, as shown in Figure 2.

The tidewater glaciers are glaciers that terminate in the sea, lake or river, usually in a fjord, producing crevasses with parallel forms. The front is in the form of an ice wall where icebergs break off.

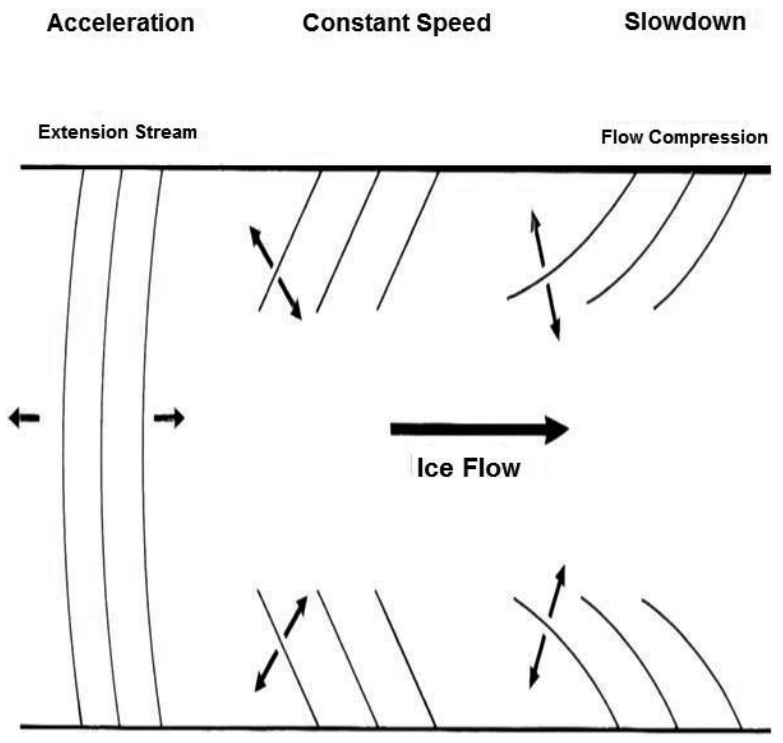

Figure 2 - Types of ice flow and different types of crevasses are formed on the surface of a glacier. Source: Hambrey (1994).

\section{STUDY AREA}

The Antarctic Peninsula is the northernmost part of the Antarctic continent with areas that extend north of the Antarctic Circle. Is located in the Western Hemisphere, relatively next to South America, extending from the north to south for $1,500 \mathrm{~km}$ between the Bellingshausen and Weddell seas. It has an internal plateau with an average elevation of 1,500 meters, with a width between 
30 and $350 \mathrm{~km}$ east-west (Ahlert, 2005). Has peaks that can reach nearly 2,800 meters of altitude.

Due to being at the periphery of the Antarctic continent, within the limits of the seasonal sea ice, and be influenced by both the subpolar cold air masses, for the masses of air of mild latitudes (polar front is in the area), the Antarctic Peninsula is more susceptible to climatic variations (De Angelis \& Skvarca, 2003). This way, variations in ocean temperatures and surface air more intensely influenced the present mass balance of glaciers (Rott et al., 2011).

The morphological characteristics of the Antarctic Peninsula mean that air masses relatively warmer and humid, coming from the west, go through the Bellingshausen Sea and lose intensity to impinge the plateau of the peninsula. In the Weddell Sea region, which is colder compared to the Bellingshausen Sea (Morris \& Vaughan, 2003), the masses of cold air from the east control the local climate. This way, the local topography acts as a natural barrier of atmospheric circulation in this peninsula (Reynolds, 1981).

Recent studies have shown that the Antarctic Peninsula presented a warming trend of $3.8 \pm 0.7^{\circ} \mathrm{C}$ over the last 100 years (1900-2000) (Morris \& Vaughan, 2003). This warming trend was more intense on the west coast of the Antarctic Peninsula, especially in the higher latitudes is more expressive in austral winter. Moreover, the seasonal snow cover on the ice-free areas has been decreasing over time in this region (Vaughan, 2006).

In recent decades, the glaciers of the Antarctic Peninsula presented great loss of ice mass, mainly through the retraction of its fronts (Simões et al., 1999; Rott et al., 2002; De Angelis \& Skvarca, 2003; Arigony-Neto et al., 2007; Pritchard \& Vaughan, 2007). Furthermore, the increase of surface air temperature occurred in this region (De Angelis \& Skvarca, 2003) causing an imbalance in the mass balance of these glaciers (Rott et al., 2011), and the melting of surface snow hit in recent years, areas with higher and higher altitude (Arigony-Neto et al., 2009). The greater persistence of the conditions of ablation and the largest volume of water melting are some of the factors that may be promoting the acceleration of the flow of local glaciers (Cook et al., 2005).

\section{METHODOLOGY}

To estimate and analyze the flow rate of Antarctic Peninsula glaciers, pairs of multitemporal LANDSAT images of the sensors TM and ETM+ were used. Images were processed with a cross-correlation algorithm to extract feature vectors of displacement of these pairs of images. The displacement of features on the surface of glaciers corresponds to the displacement thereof during the time period between the acquisition of the images. In addition, data of sea surface and air temperature respectively of OCCAM (Ocean Circulation and Climate Advanced Modeling) and ERA-Interim (Interim Reanalysis Project) models were used to analyze the influence of these parameters on the flow rate of glaciers analyzed.

The images used were obtained by LANDSAT 4, 5 and 7 , launched in 1982, 1984 and 1999, respectively. The main imaging instrument of LANDSAT 4 and 5 is the Thematic Mapper (TM) sensor. The LANDSAT 7 satellite sensor has the Enhanced Thematic Mapper Plus (ETM+). The LANDSAT images are available for download at the United States Geological Survey webpages (USGS, http://edcsns17.cr.usgs.gov/NewEarthExplorer/).

LANDSAT images are useful for estimating the flow rate of glaciers, because they provide a synoptic view of an area of 185 $\times 185 \mathrm{~km}$ (Luchitta et al., 1993) and a spatial resolution of 30 meters. Thus, several fixed points in each scene (i.e., ground control points), required for geometric correction and co-registration of images, can be found (Luchitta et al., 1993). Moreover, this type of orbital image is widely used in glaciology (Bindschadler et al., 2008) and is the oldest series of images with medium spatial resolution used for studies of changes in the Earth's surface.

To determine the velocity of glaciers in the study areas, the near-infrared band (i.e., band 4 of TM and ETM+ sensors) was used because it has high sensitivity to variations in the roughness of the surface features of glaciers (Turrin, 2010).

To obtain good results in the analysis glaciers dynamics is important to use data with suitable temporal resolution. However, this is not always possible with use data from optical sensors, due to the high frequency of cloud cover on the Antarctic Peninsula. In this study, LANDSAT images were separated in pairs, with a mean interval of one year.

The LANDSAT images used in this study were already georeferenced, but between pairs of images acquired in the same path and row, errors found were around $100 \mathrm{~m}$, or almost 4 pixels (USGS, 2007). For the extraction of displacement vectors with cross-correlation algorithms, the pairs of images must be coregistered (Scambos et al., 1992). Thus, it was necessary to register the image pairs using from 25 to 47 ground control points (GCPs) per pair of images and having a root mean square error (RMS) between 0.5 and 1 pixel, i.e., each pair of images has a positioning error equivalent up to $30 \mathrm{~m}$.

For the spatial analysis of variations in flow velocities, 44 glaciers were selected along the Antarctic Peninsula, and the the Antarctic Peninsula was divided into 5 sectors (Fig. 3), accord- 


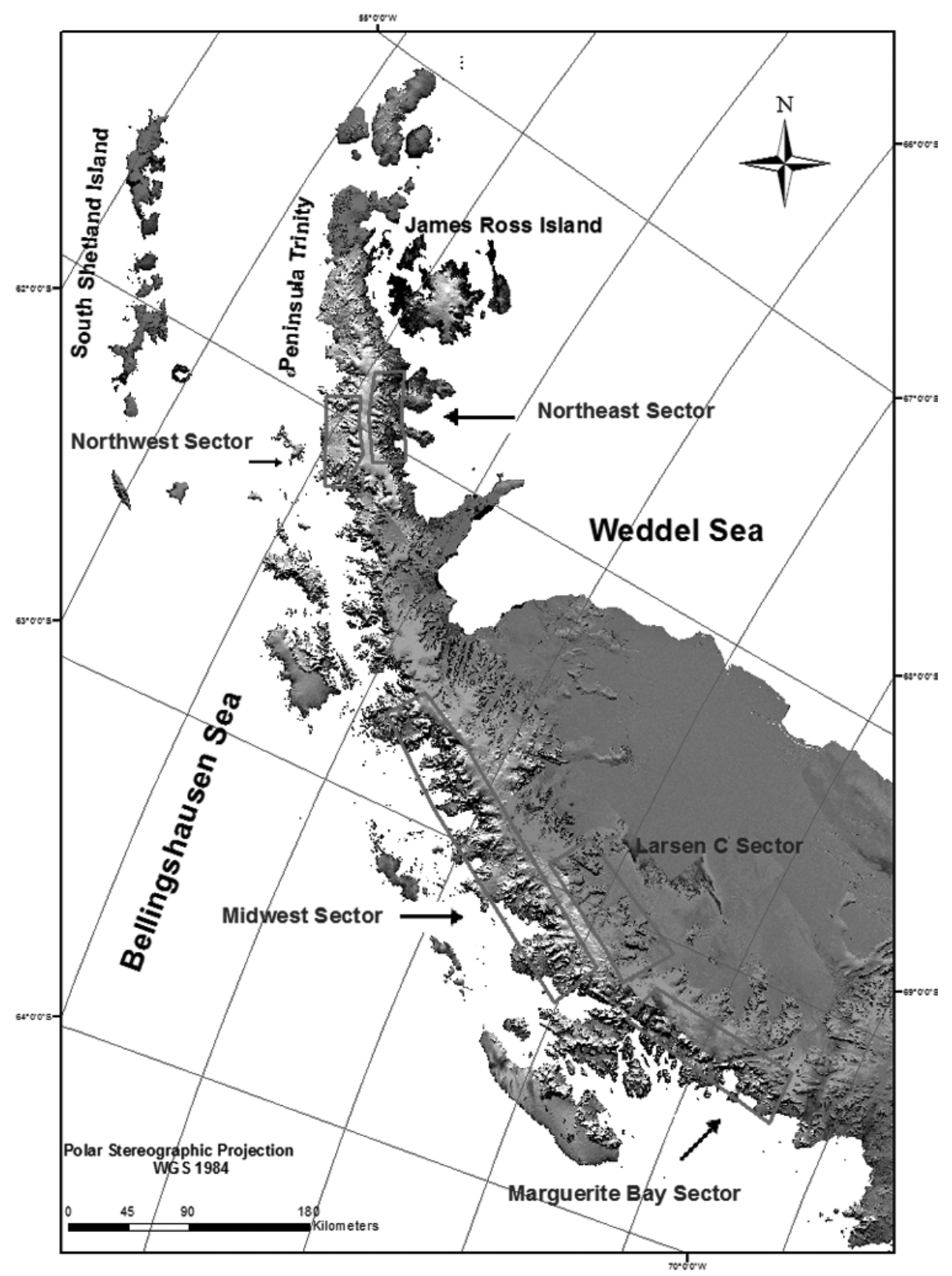

Figure 3 - Location of sectors selected for the study of the flow velocity glaciers of the Antarctic Peninsula, on the mosaic LIMA (USGS, 2007).

ing to the location data and the topography of the region. Thus, 5 selected glaciers are located in the northeast sector, 4 in the northwest sector, 20 in the Midwest sector, 7 in Marguerite Bay sector and 8 in the Larsen $\mathrm{C}$ ice shelf sector. All selected in Northeast, Midwest, northwest, and Marguerite Bay sectors are tidewater glaciers. The glaciers of the Larsen $C$ sector are tributary glaciers merging into the Larsen $\mathrm{C}$ ice shelf. For each glacier, the central area was selected for measuring the velocity, ranging from its top to its base.
Each pair of LANDSAT was processed through the crosscorrelation algorithm implemented in the IMCORR software (Scambos et al., 1992). The IMCORR was developed to anaIyze two sequential images, calculating the displacement of surface features identified in both images (Bindschadler \& Scambos, 1991). Initially, the normalized covariance will adjust the intensity values of the pixels selected in the reference images and search windows, making the average equal to zero, and then the results within the search area are compared with the reference area. 
This search algorithm is performed pixel by pixel, with reference to the center pixel of the search window. After finding the peak correlation between the features, the algorithm calculates the distance between pixels, thus generating a displacement vector (NSIDC, 2011). The correlation coefficient between the two windows is given by Equation (1):

$$
\begin{gathered}
C I_{(L, S)}= \\
\frac{\sum_{l, s}\left(r_{(l, s)}-\mu_{r}\right)\left(S_{(l, s)}-\mu_{s}\right)}{\left[\sum_{l, s}\left(r_{(l, s)}-\mu_{r}\right)^{2}\right]^{1 / 2}\left[\sum_{l, s}\left(S_{(l, s)}-\mu_{s}\right)^{2}\right]^{1 / 2}}
\end{gathered}
$$

where $C I_{(L, S)}$ is the correlation coefficient between the two images from the search area with the central pixel located at position $L, S$. The $r_{(l, s)}$ is the value of brightness in the reference window located at position $l, s$. The $\mu_{r}$ is the average of the intensity values in the reference window. The $S_{(l, s)}$ is the brightness value of the pixel in the search window located at position $l, s$. And the $\mu_{s}$ is the average value of brightness in the search window (Scambos et al., 1992).

With the calculation of correlation values and the value of the peak $C I$, used to select the homologous feature and feature reference, the calculation shows how many pixels the feature moved.

For enhancement of surface features of glaciers in LANDSAT images, high-pass, directional filters and histogram matching were applied. This procedure evidence surface features in the images, with the purpose of later use in the method of crosscorrelation.

The filter consists of a processing pixel by pixel of the images (convolution operation), and depends upon the gray level of the pixel to be modified and the value of the gray levels of neighboring pixels in the original image, i.e., filtered pixel has a value dependent on the context of the pixels in the original image (Turrin, 2010).

In the first experiment, window sizes of $128 \times 128$ and $64 \times 64$ pixels were used for the reference image and the search image, respectively, with a moving window of 10 pixels. If this method was used pixel by pixel, the results would be redundant. In another experiment, window sizes of $128 \times 32,128 \times 16$, $64 \times 32,64 \times 16$ and $32 \times 16$ pixels were used, for search and reference images, respectively.

For each different size of windows, were processed images with high-pass and directional filters with windows of $3 \times 3$, $5 \times 5,7 \times 7,9 \times 9$ and $11 \times 11$ pixels, and pairs of images processed by histogram matching. Furthermore, the algorithm was also tested using pairs of images without any filtering. Thus, 70 tests for each pair of images have been performed.
Important to consider that different window sizes were tested with IMCORR, as the most appropriate window size depends on the flow rate of each glacier.

The most consistent results were obtained using search windows with $128 \times 128$ pixels and reference windows with $64 \times 64$ pixels, with the search area about every 10 pixels, starting $x$ and $y$ in the upper left corner of the image, covering the entire image, and without any filtering.

\section{Meteorological parameters}

Monthly averages of surface air temperatures were calculated for the ablation season (December to March) of the periods 19891990 and 2000-2003 for the analysis of the influence of meteorological parameters on the flow dynamics of glaciers.

The ECMWF model has a spatial resolution of $1.5^{\circ}$. Uses a time window of 12 hours and $4 \mathrm{D}$ variational analysis for a spectral grid with triangular truncation of 255 waves, corresponding to approximately $80 \mathrm{~km}$, and a system of hybrid vertical coordinate with 60 levels. The reanalysis data are modeled by interpolation of data points collected at the surface in weather stations and interpolated statistically in time.

Each point of the model was interpolated by the method of bilinear interpolation to a resolution of $200 \mathrm{~m}$, and a correction of $-0.0044^{\circ} \mathrm{C} \mathrm{m}^{-1}$ was applied to correct the vertical gradient of air temperature (Morris \& Vaughan, 2003). The digital elevation model (DEM) from the RADARSAT Antarctic Mapping Project (RAMP) (Liu et al., 2001), was used as a source of elevation data for the application of a correction rate of the surface air temperature in relation to altitude.

\section{Oceanographic parameters}

The flow rate of tidal glaciers depends on the surface temperature of the oceans, among several other factors (Nesje \& Dahl, 2000). With increased ocean temperatures, the amount of sea ice in front of glaciers decreases, thus enabling greater action of waves and tides in the process of calving. In addition, an increase in temperature of the ocean surface contributes to the lubrication of ice-rock contact at the front portion of the tidewater glaciers (Zwally et al., 2002). Considering the influence of this factor on the flow dynamics of this kind of glaciers, ocean temperature data were compared with the mean velocity of the tidewater glaciers analyzed in this study.

Temperature data for Weddell and Bellingshausen seas were used from the OCCAM model.

The OCCAM model uses the primitive equations formulated in the type $z$ coordinates Bryan-Semtner-Cox (Bryan, 1969; 
Semtner, 1974; Cox, 1984). The data used has a horizontal resolution of $1 / 12^{\circ}$ latitude and longitude. The model has a grid Arakawa type $B$, which allows the model to evaluate two series on the same grid. We used temperature data austral summers of 1989-1990 and 2000-2003 periods because this model offers data from 1988 to 2004 and because it the first model year, was ruled out in this study dates from 1988. The model adopts a grid with 66 levels in the $z$ coordinate, but this analysis only considered the first 3 levels.

\section{RESULTS}

The following results correspond to the daily average in meters of the surface flow rate for the analysis of selected glaciers located in five sectors of the Antarctic Peninsula (Table 1).

Table 1 - Daily flow velocity of the glaciers examined in the study, by sectors of the Antarctic Peninsula.

\begin{tabular}{|c|c|c|}
\hline Sector & Period & Displacement speed \\
\hline Northeast & $1989-1989$ & $0.24 \pm 0.12 \mathrm{md}^{-1}$ \\
Northeast & $2001-2002$ & $0.06 \pm 0.02 \mathrm{md}^{-1}$ \\
Northwest & $1989-1990$ & $0.10 \pm 0.05 \mathrm{md}^{-1}$ \\
Northwest & $2000-2001$ & $0.22 \pm 0.13 \mathrm{md}^{-1}$ \\
Midwest & $1989-1991$ & $1.06 \pm 0.86 \mathrm{md}^{-1}$ \\
Midwest & 2001 & $0.84 \pm 0.78 \mathrm{md}^{-1}$ \\
Marguerite Bay & $1988-1989$ & $1.28 \pm 0.77 \mathrm{md}^{-1}$ \\
Marguerite Bay & 2001 & $0.23 \pm 0.12 \mathrm{md}^{-1}$ \\
Larsen C & $1988-1989$ & $0.80 \pm 0.20 \mathrm{md}^{-1}$ \\
Larsen C & $2000-2003$ & $0.15 \pm 0.10 \mathrm{md}^{-1}$ \\
\hline
\end{tabular}

In the northeastern sector, the values of average displacement velocity calculated by cross-correlation in 1988-1989 was $0.24 \pm 0.12 \mathrm{md}^{-1}$. Already in the years 2001-2002, the sector presented an average displacement velocity of $0.06 \pm 0.02 \mathrm{md}^{-1}$.

The mean and standard deviation of daily flow rate of glaciers in the northwestern sector of the Antarctic Peninsula, estimated from the pairs of images January 17, 1988 and January 28, 1989 was $0.10 \pm 0.05 \mathrm{md}^{-1}$. For the same sector, the pair of LANDSAT ETM+ images acquired on February 21, 2001 and November 31,2001 , found a mean flow velocity of the glaciers of $0.22 \pm$ $0.13 \mathrm{md}^{-1}$.

The mean flow velocity of glaciers in the central-western sector of the Antarctic Peninsula in the period 1989-1991 was $1 \pm$ $0.86 \mathrm{md}^{-1}$, while in 2001, glaciers in the central-western sector had an average velocity of $0.84 \pm 0.78 \mathrm{md}^{-1}$.

The Marguerite Bay sector between 1988 and 1989, the average flow velocity of the glaciers was $1.28 \pm 0.77 \mathrm{md}^{-1}$. In
2001, the same sector showed a superficial average flow rate of $0.23 \pm 0.12 \mathrm{md}^{-1}$.

Finally, the section of the Larsen $C$ ice shelf had an average flow rate of $0.80 \pm 0.20 \mathrm{md}^{-1}$, in the period 1989-1988. While between 2000 and 2003, the average velocity of surface flow in this sector was estimated at $0.15 \pm 0.10 \mathrm{md}^{-1}$.

\section{DISCUSSION}

The northwest sectors, Midwest and Marguerite Bay are nearby to the Bellingshausen Sea, a region where cyclones occur more frequently during the summer, even causing precipitation in liquid form. These regions have no sea ice in summer, and have a polar marine climate which causes them to be more hot and humid compared to the east coast of the Antarctic Peninsula, where are the northwest and Larsen $\mathrm{C}$ sector. The latter are in colder dry climate, with a rapid and and little pronounced warming in summer and autumn.

In the northeast sector, were also found values of flow rate $0.15 \pm 0.07 \mathrm{md}^{-1}$ for the Sjöergren glacier $\left(64^{\circ} 14^{\prime} \mathrm{S}, 59^{\circ} 8^{\prime} \mathrm{W}\right)$ and $0.34 \pm 0.58 \mathrm{md}^{-1}$ for the Boydell glacier $\left(64^{\circ} 8^{\prime} \mathrm{S}, 59^{\circ} 7^{\prime} \mathrm{W}\right)$. The average northeastern sector in 1989-1990 was $0.24 \pm$ $0.12 \mathrm{md}^{-1}$. However, in the period between December 31, 2001 and December 18, 2002, the northeast sector presented an average displacement velocity $0.06 \pm 0.02 \mathrm{md}^{-1}$. During this period, the glacier Sjöergren showed an average velocity of 0.08 $\pm 0.04 \mathrm{md}^{-1}$, while Boydell Glacier, an average velocity of 0.04 $\pm 0.02 \mathrm{md}^{-1}$. In the period 2001-2002, the Edgeworth Glacier $\left(64^{\circ} 19^{\prime} \mathrm{S}, 59^{\circ} 51^{\prime} \mathrm{W}\right)$ had an average speed of $0.10 \pm 0.03 \mathrm{md}^{-1}$, very higher than that estimated for Bombardier glacier $\left(64^{\circ} 20^{\prime} \mathrm{S}\right.$, $60^{\circ} 05^{\prime} \mathrm{W}$ ), of $0.04 \pm 0.01 \mathrm{md}^{-1}$, and Dinsmoor $\left(64^{\circ} 23^{\prime} \mathrm{S}\right.$, $\left.60^{\circ} 3^{\prime} \mathrm{W}\right), 0.04 \pm 0.04 \mathrm{md}^{-1}$.

The Sjöergren and Boydell glaciers had a reduction in their average daily flow rate for the period 2001-2002, compared to 1989-1990, which may be associated with the lowest mean surface air temperature, which was around $0^{\circ} \mathrm{C}$ in summer the 1989-1990 and around $-1^{\circ} \mathrm{C}$ in the most recent period (Fig. 4). This is confirmed by the study of Turner et al. (2005), who observed that the surface air temperature in the Peninsula was lower in 2001 than in relation to 1990.

In 1995, the ice shelves Larsen A and Prince Gustav disintegrated (De Angelis \& Skvarca, 2003) and this process was influenced by the previous heating period in this region (Rott et al., 1996). Before this event, the Edgeworth, Bombardier and Dinsmoor glaciers moved at a relatively high velocity of $2.9 \mathrm{md}^{-1}$ (De Angelis \& Skvarca, 2003), compared to the estimated by this study. According Skvarca \& De Angelis (2003), the Sjöergren and 

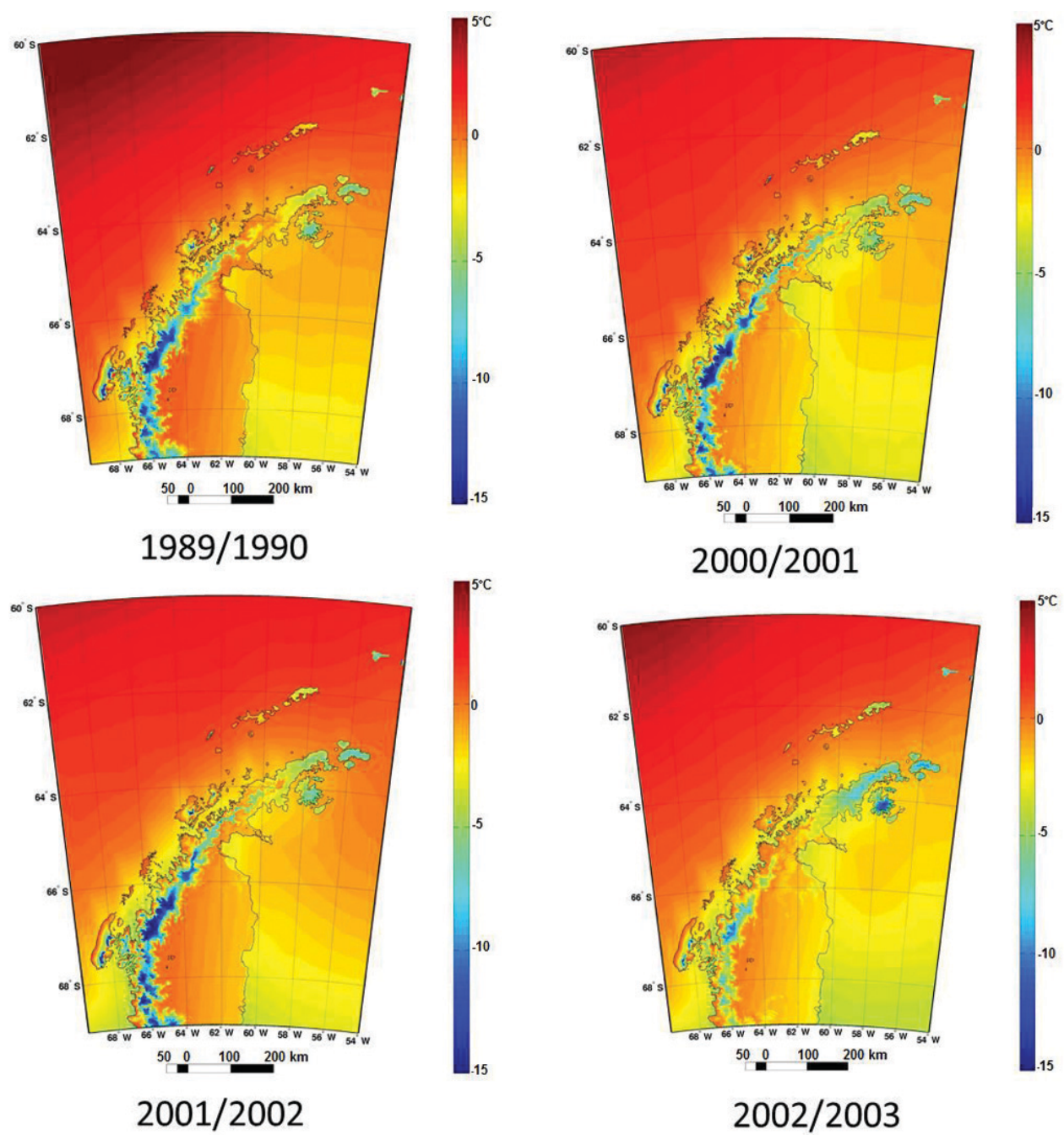

Figure 4 - Average temperature of the surface air $\left({ }^{\circ} \mathrm{C}\right.$ ), for the austral summers of 1989-1990, 2000-2001, 2001-2002 and 2002-2003. The coast line of the Antarctic Peninsula, is corrected to the present day, does not match the format in the summers of the $90 \mathrm{~s}$.

Boydell glaciers have a loss of ice mass from $12.1 \mathrm{~km}^{2}$ in March 2001, while in the same period, Edgeworth, Bombardier and Dinsmoor glaciers had a loss of approximately $6.5 \mathrm{~km}^{2}$.

On the average sea surface temperature (Fig. 5), can be observed that in the years 1989-1990 the temperature is maintained above $2.5^{\circ} \mathrm{C}$, higher than 2001-2002, where the temperature remained below $1.5^{\circ} \mathrm{C}$. That would explain a higher flow rate of glaciers Sjöergren and Boydell in 1989-1990, compared to 2001-2002. Moreover, according to Mendes Júnior (2011), in the summer of 1989 to 1990 the surface zone of wet snow was more pronounced in the northeast of the Antarctic Peninsula than in summer 2000-2001. According Arigony-Neto et al. (2007), the average surface air temperature recorded at the Marambio Base weather station $\left(64^{\circ} 14^{\prime} \mathrm{S}, 56^{\circ} 37^{\prime} \mathrm{W}\right)$ during this period was approximately $-2.8^{\circ} \mathrm{C}$.
For Gregory $\left(64^{\circ} 8^{\prime} \mathrm{S}, 60^{\circ} 48^{\prime} \mathrm{W}\right)$ and Sikorsky $\left(64^{\circ} 12^{\prime} \mathrm{S}\right.$, $60^{\circ} 51^{\prime} \mathrm{W}$ ) glaciers, located in the northwest sector of the Antarctic Peninsula, the average velocity of flow was estimated $0.10 \pm$ $0.005 \mathrm{md}^{-1}$ in the period 1989-1990. The average ocean temperature in the respective years was below $0.5^{\circ} \mathrm{C}$. The surface air temperature remained in this period with mean values near of $0^{\circ} \mathrm{C}$.

Still in the northwest sector of the Antarctic Peninsula, the Temple glacier $\left(63^{\circ} 59^{\prime} \mathrm{S}, 60^{\circ} 08^{\prime} \mathrm{W}\right)$, Breguet $\left(64^{\circ} 11^{\prime} \mathrm{S}\right.$, $60^{\circ} 48^{\prime} \mathrm{W}$ ), Gregory and Sikorsky had an average flow rate of $0.22 \pm 0.13 \mathrm{md}^{-1}$ in the period 2000-2001. For the period 19881990, the glaciers in this sector had accelerated in its flow, which can be explained by the higher ocean temperatures, which were in close proximity to $1^{\circ} \mathrm{C}$.

In the Trooz glacier ( $\left.65^{\circ} 20^{\prime} \mathrm{S}, 63^{\circ} 51^{\prime} \mathrm{W}\right)$, Belgica $\left(65^{\circ} 23^{\prime} \mathrm{S}\right.$, $\left.63^{\circ} 46^{\prime} \mathrm{W}\right)$ and Somers $\left(65^{\circ} 22^{\prime} \mathrm{S}, 63^{\circ} 33^{\prime} \mathrm{W}\right)$, located in the 

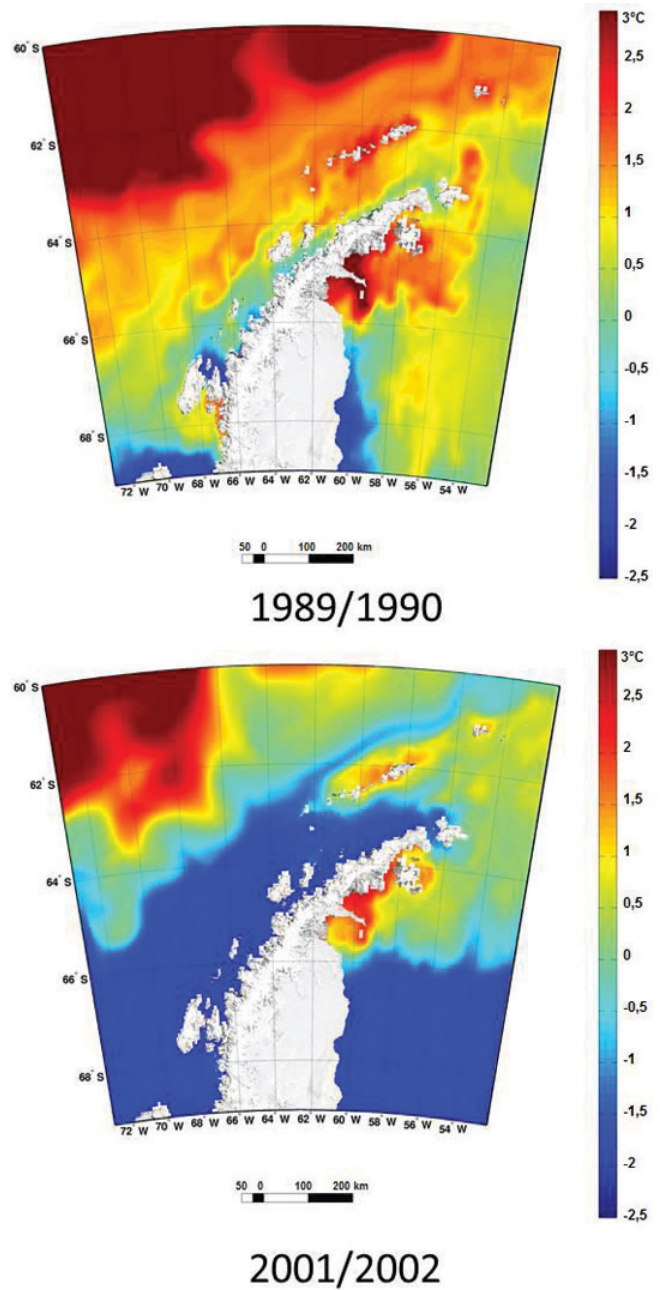

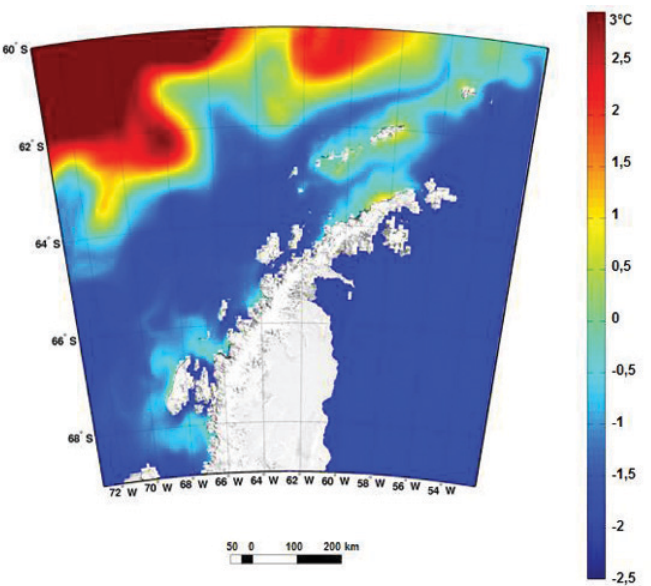

$2000 / 2001$

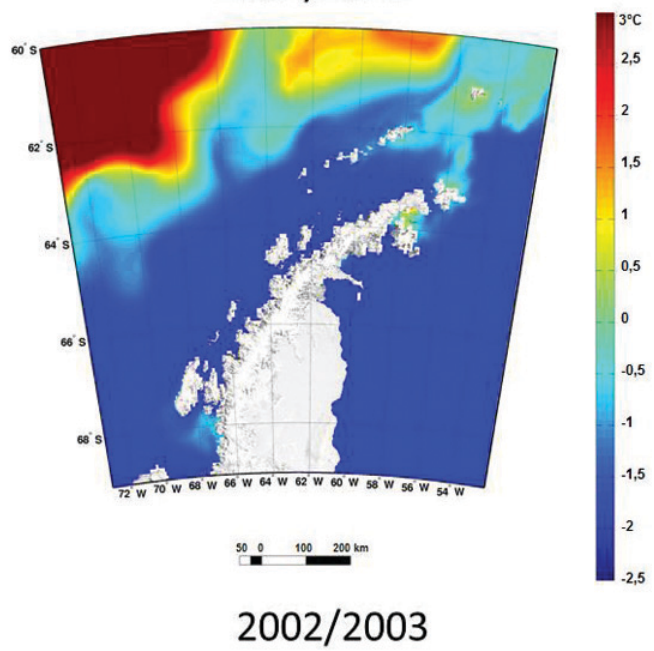

Figure 5 - Average temperature of the surface ocean $\left({ }^{\circ} \mathrm{C}\right)$ for the austral summers of 1989-1990, 2000-2001, 2001-2002 and 2002-2003. The coast line of the Antarctic Peninsula, is corrected to the present day, does not match the format in the summers of the 90s.

central-western sector of the Antarctic Peninsula, between the period 19 February 1989 to 26 November 1989 was estimated an average flow rate of $0.32 \pm 0.1 \mathrm{md}^{-1}$. In the Comrie $\left(65^{\circ} 48^{\prime} \mathrm{S}, 64^{\circ} 6^{\prime} \mathrm{W}\right)$, Pollard $\left(65^{\circ} 50^{\prime} \mathrm{S}, 64^{\circ} 8^{\prime} \mathrm{W}\right)$, Bradford $\left(65^{\circ} 53^{\prime} \mathrm{S}, 64^{\circ} 18^{\prime} \mathrm{W}\right)$, Birley $\left(66^{\circ} 2^{\prime} \mathrm{S}, 64^{\circ} 48^{\prime} \mathrm{W}\right)$, Lawrie $\left(66^{\circ} 5^{\prime} \mathrm{S}, 64^{\circ} 33^{\prime} \mathrm{W}\right)$, Weir $\left(66^{\circ} 45^{\prime} \mathrm{S}, 64^{\circ} 42^{\prime} \mathrm{W}\right)$, Erskine $\left(66^{\circ} 29^{\prime} \mathrm{S}, 65^{\circ} 27^{\prime} \mathrm{W}\right)$, Hopkins (66 $\left.36^{\prime} \mathrm{S}, 65^{\circ} 34^{\prime} \mathrm{W}\right)$, Widdowson $\left(66^{\circ} 46^{\prime} \mathrm{S}, 65^{\circ} 41^{\prime} \mathrm{W}\right)$, Drummond ( $\left.66^{\circ} 42^{\prime} \mathrm{S}, 65^{\circ} 32^{\prime} \mathrm{W}\right)$, Murphy $\left(66^{\circ} 56^{\prime} \mathrm{S}, 66^{\circ} 17^{\prime} \mathrm{W}\right)$ and Wikinson (66 $66^{\circ} \mathrm{S} \mathrm{S}, 66^{\circ} 17^{\prime} \mathrm{W}$ ) glaciers was estimated an average flow rate of $2.05 \pm 0.1 \mathrm{md}^{-1}$, between 7 February 1990 and 09 February 1991. The ocean average temperature in the summer of $1989-1990$ was around $0^{\circ} \mathrm{C}$. The air temperature at the surface showed positive values, around $1^{\circ} \mathrm{C}$. Between February 21, 2001 and December 20, 2001, glaciers in the central-western sector had an average speed of $0.84 \pm 0.78 \mathrm{md}^{-1}$.
Compared with the average displacement of the sector between 1989-1991, which was $1.06 \pm 0.86 \mathrm{md}^{-1}$, the average velocity of these glaciers has decreased. In this region, the ocean temperatures also decreased, were around of $-1.5^{\circ} \mathrm{C}$, and surface air temperatures were below $0^{\circ} \mathrm{C}$.

The sector of Marguerite Bay, where are the Perutz $\left(67^{\circ} 36^{\prime} \mathrm{S}\right.$,

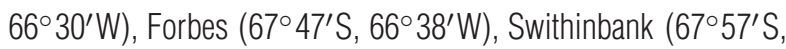

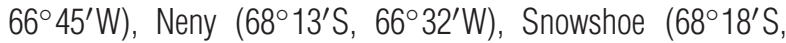

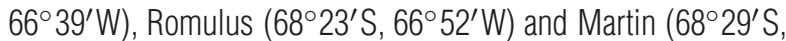
$66^{\circ} 54^{\prime} \mathrm{W}$ ) glaciers, had an average flow rate of $1.28 \pm 0.77 \mathrm{md}^{-1}$ the period between December 25, 1988 to November 26, 1989. The ocean and air temperatures showed comparatively high values, above $1^{\circ} \mathrm{C}$ in the region during this period. Already between January 27, 2001 to November 20, 2001, in the Marguerite Bay region where are Perutz, Forbes and Swithinbank glaciers, 
an average velocity was observed $0.23 \pm 0.12 \mathrm{md}^{-1}$. In this sector, the ocean temperature was around $-1.5^{\circ} \mathrm{C}$, and the surface air temperature was also below $0^{\circ} \mathrm{C}$, which explains the deceleration of its glaciers in the sector.

The sector of the Larsen $C$ ice shelf, where are located Gloud $\left(66^{\circ} 47^{\prime} \mathrm{S}, 64^{\circ} 37^{\prime} \mathrm{W}\right)$, Breitfess (66 $\left.58^{\circ} \mathrm{S}, 64^{\circ} 51^{\prime} \mathrm{W}\right)$, Cump-

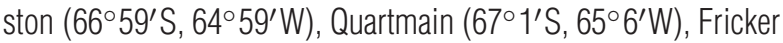
$\left(67^{\circ} 3^{\prime} \mathrm{S}, 65^{\circ} 5^{\prime} \mathrm{W}\right)$, Hess $\left(67^{\circ} 13^{\prime} \mathrm{S}, 64^{\circ} 57^{\prime} \mathrm{W}\right)$, Balck ( $66^{\circ} 51^{\prime} \mathrm{S}$, $\left.64^{\circ} 49^{\prime} \mathrm{W}\right)$, Flint $\left(67^{\circ} 20^{\prime} \mathrm{S}, 65^{\circ} 25^{\prime} \mathrm{W}\right)$ and Demorest $\left(67^{\circ} 21^{\prime} \mathrm{S}\right.$, $65^{\circ} 35^{\prime} \mathrm{W}$ ) glaciers, showed an average flow rate of $0.80 \pm$ $0.20 \mathrm{md}^{-1}$ during 1988-1989. This sector is the coldest part of the Antarctic Peninsula, compared to all other regions have warmed in recent summers (Cook et al., 2005). In 2000 and 2003, the Larsen $\mathrm{C}$ ice shelf sector where are the Flint and Demorest glaciers was estimated an average flow rate of $0.15 \pm 0.10 \mathrm{md}^{-1}$. The ocean temperatures were below $-1.5^{\circ} \mathrm{C}$, in all summer studied in this sector, surface air temperatures were negative, however near $0^{\circ} \mathrm{C}$.

The period 1989-1990 was warmer compared to 2000-2003, in the northeastern sector, Midwest, Marguerite Bay and Larsen C. Only in the northwest sector air temperature remained higher in the 2000-2003 period for the years 1988-1990. The temperature at the ocean surface has remained close to $0^{\circ} \mathrm{C}$ in almost all the Antarctic Peninsula in the period 1989-1990 and early 2000s occurred positive temperatures. Only in the Larsen $\mathrm{C}$ ice shelf region these always remained negative.

In the northeast sector of the Antarctic Peninsula in the average temperature of the ocean surface (Fig. 5) in summer 2001-2002 had positive values above $1^{\circ} \mathrm{C}$.

The average temperatures of the ocean as well as the average air temperature (Fig. 4), remained negative during the summers 2000-2003. Comparing the data of ocean temperature data with the daily average displacement velocity of glaciers on the Antarctic Peninsula, it was observed that the period between 1989-1990 showed higher temperatures, compared to the period 2000-2003. Unlike the average ocean temperatures, the surface air temperatures for almost all regions studied showed positive mean values during the austral summer, that the latter had greatest oscillation than the ocean. The sectors analyzed in this study that had a greater difference in the flow velocity of the glaciers were those presenting the highest oscillation of the surface air temperature. In northwest and central-western sectors of the Antarctic Peninsula, temperatures were elevated in all summers studied, possibly because these sectors are located in the Bellingshausen Sea, with a warmer and wetter polar maritime climate in relation to the Weddell Sea, pseudocontinental, it is cold and dry.

\section{CONCLUSIONS}

In this study were generated temporal data of the average daily flow velocity of glaciers in different sectors of the Antarctic Peninsula during the periods of 1989-1991 and 2000-2003, from LANDSAT TM and ETM+.

The glaciers of the Antarctic Peninsula in the northeast sector had an average displacement velocity of $0.24 \pm 0.12 \mathrm{md}^{-1}$ in 1988-1989. From 2000 to 2002, his average velocity was significantly lower, $0.06 \pm 0.02 \mathrm{md}^{-1}$. Located north of the Antarctic Peninsula and calving to the Weddell Sea, the significant decrease in average displacement velocity of glaciers can be validated by studies showing that the Weddell Sea presented higher values of sea and surface air temperatures in the decade of 1990.

The northwest sector of the Antarctic Peninsula presented mean values of displacement velocity glaciers of $0.10 \pm$ $0.005 \mathrm{md}^{-1}$, the period 1989-1990, and $0.22 \pm 0.13 \mathrm{md}^{-1}$, at 2000-2001. Located north of the Bellingshausen Sea ocean temperature and surface air presented high values in the early 2000s for the period 1988 to 1991, which explains the higher rate of flow of glaciers for the period.

In central-western sector, the average speed was $1.06 \pm$ $0.86 \mathrm{md}^{-1}$ between the years 1989-1991. In 2001, his average speed was $0.84 \pm 0.78 \mathrm{md}^{-1}$.

In the Marguerite Bay sector, the average displacement velocity of glaciers was $1.28 \pm 0.77 \mathrm{md}^{-1}$ in the period 1988-1989 and of $0.23 \pm 0.12 \mathrm{md}^{-1}$ at 2001. The ocean temperatures in this sector have values near of $0^{\circ} \mathrm{C}$ in austral summer 1988-1989 and of $-2^{\circ} \mathrm{C}$ at 2000-2001. Air temperatures in summer 19881989 were positive and negative in summer 2000-2001. This sector, located south of the Antarctic Peninsula, showed the highest variation of mean flow velocity of glaciers.

In the Larsen $\mathrm{C}$ ice shelf sector, the average flow velocity was $0.80 \pm 0.20 \mathrm{md}^{-1}$ in the period 1988-1989 and of $0.15 \pm$ $0.10 \mathrm{md}^{-1}$ at 2000-2003. Temperatures in this region were always lower compared to the rest of the analyzed sectors of the Antarctic Peninsula, but like almost all cases cited above, the austral summer of 1989-1990 had ocean temperatures and higher surface air in relation to the summers between 2000 and 2003.

These data were compared with surface temperatures of the air and ocean and it was found that temperatures were higher in the period 1988-1991 compared to the 2000-2003 period, which coincides with the increase found in the displacement velocity of the glaciers northeast, midwest, Marguerite Bay and Larsen C sectors. Only in the northwest sector, the flow velocity of the glaciers increased in the 2000s compared to 1990, which can be explained by the higher average temperatures recorded in the early 2000s in relation for the period 1988-1991. 
The higher velocity of glaciers occurred at a higher temperature period. This indirect correlation suggests that the end of century XX had high temperatures, causing the acceleration of the displacement flow of ice from glaciers studied.

The images obtained by optical sensors, despite showing good results in the cross-correlation (Bindschadler; Scambos, 1991), do not form a representative time series on the Antarctic Peninsula for these analyzes due to frequent cloud cover. For future studies, other methods can be developed based on the synergistic use of optical and RADAR data for the construction of larger temporal series of images of the Antarctic Peninsula, with the aim of extracting a larger volume of information on the flow velocity of glaciers of this peninsula.

\section{REFERENCES}

AHLERT S. 2005. Variações morfológicas do campo de gelo da ilha Brabant, Antártica. Master dissertation (Sensoriamento Remoto) - Centro Estadual de Pesquisas em Sensoriamento Remoto e Meteorologia, Universidade Federal do Rio Grande do Sul, Porto Alegre, 2005. 102 pp.

ARIGONY-NETO J, RAU F, SAURER H, JAÑA R, SIMÕES JC \& VOGT S. 2007. A time series of SAR data for monitoring changes in boundaries of glacier zones on the Antarctic Peninsula. Annals of Glaciology, 46: 55-60.

ARIGONY-NETO J, SAURER H, SIMÕES JC, RAU F, JAÑA R, VOGT S \& GOSSMANN H. 2009. Spatial and temporal changes in dry-snow line altitude on the Antarctic Peninsula. Climatic Change, 94: 19-33.

BENNETT RM \& GLASSER NF. 2009. Ice Sheets and Landforms Glacial Geology. 2nd ed., 385 pp.

BINDSCHADLER RA \& SCAMBOS TA. 1991. Satellite-image-derived velocity field of an Antarctic ice stream. Science, 252: 242-246.

BINDSCHADLER R, VORNBERGER P, FLEMING A, FOX A, MULLINS J, BINNIE D, PAULSEN SJ, GRANNEMAN B \& GORODETZKYD. 2008. The LANDSAT Image Mosaic of Antarctica. Remote Sensing of Environment, 112(12): 4214-4226.

BRYAN K. 1969. A numerical method for the study of the circulation of the world ocean. Journal of Computational Physics, 135: 153-169.

COOK A, FOX A, VAUGHAN D \& FERRIGNO J. 2005. Retreating glacier fronts on the Antarctic Peninsula over the past half-century. Science, 308: 541-544.

COX MD. 1984. A primitive equation 3-dimensional model of the ocean. GFDL Ocean Group Technical. report No. 1, Geophysical Fluid Dynamics Laboratory/NOAA Princeton University, Princeton, N.J. 08542.

CUFFEY KM \& PATERSON WSB. 2010. The Physics of Glaciers. Oxford: Pergamon. 4 ed. $480 \mathrm{pp}$.

DE ANGELIS H \& SKVARCA P. 2003. Glacier Surge After Ice Shelf Collapse. Science, 299: 1560-1562.
HAMBREY M. 1994. Glacial Environments. London: UCL Press. 296 pp.

KING JC \& TURNER J. 1997. Antarctic meteorology and climatology. Cambridge: Cambridge University Press. 409 pp.

LIU H, JEZEK KC, Li B \& ZHAO Z. 2001. Radarsat Antarctic mapping project digital elevation model version 2. National Snow and Ice Data Center, Boulder (Digital media) Meadows P, Laur H, Schättler B, 35-42.

LUCCHITTA BK, MULLINS KF, ALLISON AL \& FERRIGNO JG. 1993. Antarctic glacier-tongue velocities from LANDSAT images: first results. Annals of Glaciology, 17: 356-366.

MENDES-JUNIOR CW. 2011. Monitoramento da zona superficial de neve úmida da Península Antártica pelo uso de dados dos sensores SMMR e SSM/I. 2011. Thesis. (Instituto de Geociências) Universidade Federal do Rio Grande do Sul. Porto Alegre. 150 pp.

MORRIS EM \& VAUGHAN DG. 2003. Spatial and temporal variation of surface temperature on the Antarctic Peninsula and the limit of variability of ice shelves. In: DOMACK ELA, BURNETT A, BINDSCHALLER R, CONVEY P \& KIRBY M (Eds.). Antarctic Peninsula climate variability historical and paleoenvironmental perspectives. Washington: American Geophysical Research, p. 61-68.

NATH PC \& VAUGHAN DG. 2003. Subsurface crevasse formation in glaciers and ice sheets. Journal of Geophysical Research, 108(B1), 2020, doi: 10.1029/2001JB000453, 7 pp.

NESJE A \& DAHL SO. 2000. Glaciers and Environmental Change. London: Hodder Headline Group. 203 pp.

NSIDC - NATIONAL SNOW AND ICE DATA CENTER. 2011. IMCORR Software. Available on: <http://nsidc.org/data/velmap/imcorr.html>. Access on: July 22, 2011.

PRITCHARD HD \& VAUGHAN DG. 2007. Widespread acceleration of tidewater glaciers on the Antarctic Peninsula. Journal of Geophysical Research, Washington, 112: F03S29, doi: 10.1029/2006JF000597.

REES WG. 2006. Remote sensing of snow and ice. Boca Raton: Taylor \& Francis. $284 \mathrm{pp}$.

REYNOLDS J. 1981. The distribution of mean annual temperatures in the Antarctic Peninsula. British Antarctic Bulletin, Cambridge, 54: 123-133.

ROTT H, SKVARCA P \& NAGLER T. 1996. Rapid collapse of northern Larsen Ice Shelf, Antarctica. Science, London, 271: 788-792.

ROTT H, RACK W \& SKAVARCA P. 2002. Northern Larsen Ice Shelf, Antarctica: further retreat after collapse. Cambridge, 34: 277-282.

ROTT H, MULLER F, NAGLER T \& FLORICIOIU D. 2011. The imbalance of glaciers after disintegration of Larsen-B Ice Shelf, Antarctic Peninsula. The Cryosphere, 5: 125-134, doi: 10.5194/tc-5-125-2011.

SCAMBOS TA, DUTKIEWICZ MJ, WILSON JC \& BINDSCHADLER RA. 1992. Application of image cross-correlation to the measurement of glacier velocity using satellite image data. Remote Sensing of Environment, 42: 177-186. 
SEMTNER AJ. 1974. A general circulation model for the World Ocean. Technical Report No. 9, Department of Meteorology, University of California, Los Angeles.

SIMÕES JC, BREMER UF, AQUINO FE \& FERRON FA. 1999. Morphology and variations of glacial drainage basins in the King George Island ice field, Antarctica. Annals of Glaciology, 29: 220-224.

SIMÕES JC. 2004. Glossário da língua portuguesa da neve, do gelo e termos correlatos. Pesquisa Antártica Brasileira, Rio de Janeiro, 4: 119154.

TURNER J, COLWELL SR \& MARSHALL GJ, LACHLAN-COPE TA, CARLETON AM, JONES PD, LAGUN V, REID PA \& LAGOVKINA S. 2005. Antarctic climate change during the last 50 years. International Journal of Climatology, 25: 279-294.

Recebido em 25 julho, 2012 / Aceito em 22 janeiro, 2013

Received on July 25, 2012 / Accepted on January 22, 2013
TURRIN JB. 2010. Measuring glacier velocities on the Kenai Peninsula, Alaska, using multispectral satellite imagery with feature tracking Time. Master Dissertation (Department of Geography). University of Utah. $247 \mathrm{pp}$.

USGS. 2007. United States Geological Survey. LANDSAT Image Mosaic of Antarctica (LIMA). U.S Geological Survey Fact Sheet 2007-3116, 4 p.

VAUGHAN DG. 2006. Recent Trends in Melting Conditions on the Antarctic Peninsula and their Implications for Ice-sheet Mass Balance and Sea Level. Arctic, Antarctic, and Alpine Research, 38(1): 147-152.

ZWALLY HJ, ABDALATI W, HERRING T, LARSON K, SABA J \& STEFFEN K. 2002. Surface melt-induced acceleration of Greenland ice-sheet flow. Science, 297: 218-22.

\section{NOTES ABOUT THE AUTHORS}

Aline Barbosa da Silva. Degree in Oceanography (UNIMONTE/2009) Master in Physics, Chemistry and Geological Oceanography from the Universidade Federal do Rio Grande (FURG/2012), CAPES scholarship and doctoral student at Graduate Program Monitoring Laboratory of Cryosphere (LaCrio/FURG), working in the area of glacial dynamics in the Antarctic Peninsula via remote sensing.

Jorge Arigony Neto. Adjunct Professor at the Universidade Federal do Rio Grande (FURG). Doctor (summa cum laude, 2007) from the Institute of Physical Geography at the University of Freiburg (Albert-Ludwigs-Universität, Germany). Bachelor of Geography from the Universidade Federal do Rio Grande do Sul (UFRGS, 1997) and a Masters in Remote Sensing (2001) from the same university. Coordinates the Monitoring Laboratory of Cryosphere (LaCrio/FURG), coordinates research projects and teaching CNPq and CAPES, lead Group for Remote Sensing of Cryosphere of the National Institute of Science and Technology (INCT) the Cryosphere.

Cláudio Wilson Mendes Júnior. Professor of Oceanography at the Universidade Federal do Rio Grande (FURG). Doctor in Sciences Graduate Program in Geosciences, Universidade Federal do Rio Grande do Sul (UFRGS) and Bachelor of Geography in 1997 and Master in Remote Sensing in 2002 (CEPSRM). Scholarship from CAPES (PNPD), acting as an investigator of the Monitoring Laboratory of Cryosphere (LaCrio/FURG), National Institute of Science and Technology (INCT) of the Cryosphere.

Adriano Gomes de Lemos. Water Resources Engineering from the Universidade Federal de Itajubá (UNIFEI), Master of Physical Oceanography, Universidade Federal do Rio Grande (FURG). Currently working in the Monitoring Laboratory of Cryosphere (LaCrio/FURG). Research focused on the dynamics of ice shelves on the Antarctic Peninsula derived from climatic variations. 